\title{
Osobowościowe i aksjologiczne predyktory adaptacji do sytuacji życiowej emigranta i jego rodziny - na przykładzie polskich emigrantów w Holandii
}

Zjawisko emigracji jest jednym z nowych wyzwań XXI wieku. Jego skala w ciągu ostatnich dekad wzrosła. Przyczyną tego jest otwarcie granic państw strefy Schengen i wzrost znaczenia Unii Europejskiej na terenie Europy $^{1}$. Otwarcie granic sprawiło, że zagadnienie dotyczy nie tylko Polski, ale też całej Europy. Dodatkowym motywem, dla którego należy się zająć tym fenomenem z perspektywy naukowej, jest kryzys demograficzny ${ }^{2}$, który jest konsekwencją przechodzenia na emeryturę ludzi z tzw. pokolenia baby

P. Dąbrowski, J. Napierała, A. Piekut, Migracje międzynarodowe: Polska - Unia Europejska - Europa Wschodnia, „Biuletyn Migracyjny” 14 (2007), s. 1-10.

2 J. Świętoniowska, Starzenie się społeczeństwa europejskiego w kontekście kryzysu światowego. Czy UE nadal ma szansę stać się najbardziej konkurencyjna gospodarka światową?, „Zeszyty Naukowe Zakładu Europeistyki” 3 (2009), nr 11, s. 86-105. 
boomers ${ }^{3}$. Emigracja badana jest najczęściej pod kątem socjologicznym, jednak literatura omawiająca badania z zakresu psychologii rodziny jest bardzo uboga. Artykuł stanowi odmienne spojrzenie na emigrację, ponieważ omawia konkretną grupę Polaków poza granicami kraju, a mianowicie Polaków mieszkających w Holandii. W literaturze można odnaleźć związki między poszczególnymi cechami osobowości a poziomem adaptacji do wydarzeń trudnych, takich jak np. emigracja. Model Paula Costy i Roberta McCrae wskazuje na takie implikacje, szczególnie jeżeli mówi się o ekstrawersji, otwartości na doświadczenia, sumienności i ugodowości. Z kolei neurotyczność może być czynnikiem zaburzającym proces adaptacji. Wskazuje się również na to, że system wartości, na podstawie teorii Miltona Rokeacha, może być predyktorem przystosowania społecznego ${ }^{4}$.

\section{Emigracja}

Termin „migracja” wywodzi się z łacińskiego słowa migratio, który tłumaczy się jako wędrówkę czy też przenoszenie się mieszkańców danego kraju, regionu ${ }^{5}$. Przyczyny tego zjawiska są ekwipotencjalne. W teoriach socjologicznych zaznacza się przyczyny ekonomiczne (migracja zarobkowa) lub takie, które wynikają z przyczyn politycznych (wojna, prześladowania). Pojęciem pokrewnym „migracji” jest „emigracja”, która również ma źródłosłów łaciński. W tym przypadku słowo oznacza dobrowolne opuszczenie kraju macierzystego. Ostatnim pojęciem jest „imigracja” (łac. immigro), która odnosi się do osób przyjeżdżających do danego kraju. Migrowanie można rozważać pod wieloma względami. Przede wszystkim pod względem czasu trwania: osiedleńcze, krótkookresowe, długookresowe, wahadłowe. Istnieje wiele typologii migracji, jednak za najbardziej klasyczną uznaje się tę stworzoną przez Williama Petersena ${ }^{6}$. Wprowadził on dwa typy migracji: innowacyjny oraz konserwatywny. Celem pierwszego jest wprowadzenie

3 Baby boomers to określenie grupy społecznej ludzi urodzonych podczas powojennego wyżu demograficznego w latach 1946-1964.

$4 \quad$ P. T. Costa, R. R. McCrae, Revised NEO Personality Inventory (NEO-PI-R) and NEO Five-Factor Inventory (NEO-FFI) professional manual, Odessa 1992, s. 130.

$5 \quad$ K. Kumaniecki, Słownik łacińsko-polski, Warszawa 1964, s. 309.

6 W. Petersen, A General Typology of Migration, „American Sociological Review” 53 (1958), s. 256-266. 
zmian i podejmowanie działań, których przewidywaną konsekwencją jest stworzenie czegoś nowego. Z kolei drugi odnosi się do utrzymania status $q u o$. Wśród konserwatywnych badacz oznacza zasadnicze klasy, tj. migrację dobrowolną i przymusową ${ }^{7}$.

Problem emigracji nie jest tylko kwestią polityczną, odnosi się również do indywidualnych problemów natury psychologicznej, jednostek, ale też całych rodzin, których dotyka problem zmiany pierwotnego miejsca zamieszkania. Zmiana tak ekstremalna wymaga przystosowania. Państwa powinny oczywiście stwarzać warunki do tego, aby dochodziło do sprawnej adaptacji, jednak kluczowe są osobiste predyspozycje do przystosowania. W kontekście źródeł z dziedziny psychologii zauważa się, że emigrant musi zmierzyć się ze stratą tego, co zostawil, opuszczając swój kraj, dodatkowo starać się zapewnić sobie podstawowe rzeczy: lokum, pracę. Zwraca się również uwagę na początkowy brak kontaktów społecznych, który może potęgować stres u emigranta ${ }^{8}$.

Zaznacza się również, że w państwach, które miały wysoki poziom emigracji na początku XXI wieku, większość dzieci emigrantów cierpiało na zespół nieobecnego rodzica. Rodzic nieobecny w domu jest bardzo negatywnie postrzegany przez dziecko. $\mathrm{W}$ badaniach autobiograficznych młode pokolenie mówiło o uczuciu zagubienia, stanach depresyjnych, lękach i braku pewności siebie. Stany te często wymagały psychoterapii ${ }^{9}$.

\section{Proces adaptacji}

Emigracja stwarza możliwość założenia rodziny w większości miejsc na świecie, jednak niewątpliwie jest też sytuacją stresogenną, w której jednostka musi mierzyć się z nowymi kryzysami, z jakimi wcześniej nie miała styczności. W publikacjach z zakresu psychologii można spotkać wiele definicji pojęć „przystosowanie” czy „dostosowanie”. Przykładem może być

\footnotetext{
A. Górny, P. Kaczmarczyk, Uwarunkowania i mechanizmy migracji zarobkowych $w$ świetle wybranych koncepcji teoretycznych, „Instytut Studiów Społecznych UE” 49 (2003), s. $10-21$.

$8 \quad$ J. Kubitsky, Psychologia migracji, Warszawa 2012, s. 26.

9 Zob. M. Colson, Coping with absent parents, Hastings 2011, s. 5-15.
} 
Zbigniew Skorny ${ }^{10}$, dla którego te pojęcia są synonimami. Ważne jest tutaj jednak rozróżnienie na dostosowanie względem środowiska zewnętrznego (dostosowanie się do wymogów środowiska i obieranie ról społecznych) i środowiska wewnętrznego (odnosi się do osobowości człowieka, która kształtuje się w momencie przystosowania). Osoba, która cechuje się wysokim poziomem adaptacji, jest aktywna, wnosi do swojej społeczności nowe aktywności oraz tworzy środowisko do samorealizacji innych osób, co umożliwia jej własny rozwój ${ }^{11}$. Autorzy zauważają konieczność przeżycia przez osobę przystosowującą się wewnętrznej przemiany. W chwili kiedy nie dochodzi do żadnych zmian albo gdy są one nieadekwatne do sytuacji, wówczas możemy mówić o braku przystosowania ${ }^{12}$.

Inny polski psycholog, Kazimierz Dąbrowski ${ }^{13}$, zadaje pytanie o zdrowie psychiczne jednostki adaptującej się do sytuacji nowej dla człowieka. W swoich rozważaniach zwraca uwagę na powiązanie zdolności przystosowania się ze zdrowiem psychicznym. Otóż przystosowanie się może mieć cztery wymiary: a) przystosowanie pozytywne; b) nieprzystosowanie pozytywne; c) przystosowanie negatywne; d) nieprzystosowanie negatywne. Przez przystosowanie pozytywne autor rozumie adaptację pozytywną do wartości wyższego poziomu ${ }^{14}$, a nieprzystosowanie do postaw prymitywnych. Człowiek przystosowany pozytywnie to taki, który stawia sobie cele zbliżające go do określonego ideału indywidualnego i społecznego. Osoba taka stawia sobie za cel rozwój indywidualny, w taki sposób, aby być kimś, kto wnosi do społeczeństwa coś wartościowego. Z kolei nieprzystosowanie pozytywne oznacza izolację od wartości prymitywnych, instynktownych na poziomie społecznym i indywidualnym. Ten rodzaj nieprzystosowania jest twórczy, charakteryzuje osoby z samodzielnością rozwojową. Stanisław

10 Zob. Z. Skorny, Mechanizmy regulacyjne ludzkiego działania, Warszawa 1989, s. $98-122$.

11 J. Śliwak, U. Reizer, J. Partyka, Poczucie osamotnienia a przystosowanie społeczne, „Studia Socialia Cracoviensia” 7 (2015) nr 1, s. 61-78.

12 T. Tomaszewski, O możliwościach jednostki w sytuacjach przemian społecznych, „Kolokwia Psychologiczne” 2 (1993) nr 11, s. 20-28.

13 K. Dąbrowski, Wprowadzenie do higieny psychicznej, Warszawa 1979, s. 11-18.

14 Wartości wyższego poziomu u Dąbrowskiego dzielimy na esencję indywidualną i społeczną. Do esencji indywidualnej zaliczamy m.in. talenty i uczucia, wyłączne uczucia, świadomość własnej tożsamości i historii, rozwoju, zaś do esencji społecznej empatię, autonomię, odpowiedzialność, autentyzm, wysoki poziom świadomości społecznej. Występowanie esencji indywidualnej i społecznej jest warunkiem sine qua non istnienia wartości wyższego poziomu. 
Popek nazywa ten stan społecznym nonkonformizmem, który oznacza samodzielność $\mathrm{w}$ aspekcie myślenia i działania, do czego podstawą jest własna postawa, zbudowana $\mathrm{z}$ indywidualnych wartości uporządkowana $\mathrm{w}$ hierarchii $^{15}$. Nonkonformizm pozytywny należy również postrzegać jako umiejętność bronienia swojego punktu widzenia, mimo nacisków społecznych. Bardzo istotne jest to, że osoba nieprzystosowana pozytywnie nie może być nastawiona na łamanie norm społecznych ${ }^{16}$. Przystosowanie i nieprzystosowanie pozytywne jest uznawane przez Dąbrowskiego za zdrowie psychiczne. W procesie wychowania kształtowanie tych dwóch postaw adaptacyjnych jest podstawą higieny psychicznej ${ }^{17}$. Przystosowanie negatywne, często nieuświadomione, oznacza takie przystosowanie się do warunków i wymogów środowiska, aby czerpać z niego wyłącznie prymitywne korzyści, w taki sposób, aby inni ponosili szkody. Taka forma przystosowania najczęściej występuje u osób z pogranicza normy i zaburzeń psychicznych. Poprzez konformizm negatywny Popek rozumie takie dostosowanie, które blokuje cechy kreatywne u człowieka, nie tylko w sferze poznawczej, ale też behawioralnej ${ }^{18}$. Nieprzystosowanie negatywne charakteryzuje osoby, których postawa w interakcji ze społeczeństwem jest nieadekwatna. Osoby takie $\mathrm{w}$ kontakcie $\mathrm{z}$ innymi reagują niezgodnie $\mathrm{z}$ ogólnie przyjętymi założeniami aksjologicznymi, wymaganiami społecznymi i normami, bywają agresywne. Pomiędzy definicją adaptacji Kazimierza Dąbrowskiego i teorią Stanisława Popka można zauważyć wiele podobieństw, które można przenieść na grunt emigracji.

Koncepcja przystosowania Kazimierza Dąbrowskiego wskazuje na związek adaptacji i silnej hierarchii wartości, wyrażanej przez konformizm i nonkonformizm. Rozumienie adaptacji jako zdolności do zaspokajania własnych potrzeb wokreślonym środowisku poprzez aktywność własną warunkuje rozwój osobowości na wyższym poziomie ${ }^{19}$.

15 R. E. Bernacka, Osobowościowy mechanizm konformizmu i nonkonformizmu - specyfika funkcjonowania i przejawy w zachowaniu, „Psychologia Rozwojowa” 2 (2005) nr 2, s. $73-82$.

16 Zob. E. Aronson, T. D. Wilson, R. M. Akert, Psychologia społeczna, przekł. A. Bezwińska i in., Poznań 1997, s. 266-267.

17 K. Dąbrowski, Trud istnienia, Warszawa 1975, s. 7-15.

18 S. Popek, Kwestionariusz Twórczego Zachowania KANH, Lublin 2000.

19 Zob. K. Dąbrowski, Trud istnienia, dz. cyt., s. 12. 


\section{Rola osobowości w procesie adaptacji}

Osobowość i jej poszczególne determinanty mogą okazać się kluczowe w kontekście predykcji stylu adaptacyjnego. Już Gordon Willard Allport ${ }^{20}$ zauważa, że osobowość człowieka jest niepowtarzalną strukturą, w której znajomość zachowań i intencji przyczynia się do określenia kierunku przyszłych dążeń.

Osobowość ma istotny wpływ w kontekście adaptacji do sytuacji stresowych. Świadczyć może o tym badanie Kobasy ${ }^{21}$. W badaniach wzięło udział 250 osób, które były członkami kadry kierowniczej zakładów użyteczności publicznej. Na początku badania uzyskano dane odnoszące się do stanu zdrowia, obciążenia sytuacjami stresowymi oraz osobowości. Okazało się, że osoby z osobowością słabszą immunologicznie wykazywały dwa razy więcej objawów chorobowych niż osoby z osobowością silną immunologicznie, niezależnie od warunków stresowych ${ }^{22}$.

Wiele badań odnosi się do teorii osobowości Paula Costy i Roberta McCrae. Wśród czynników, które wymienia autor, znajdują się następujące wymiary osobowości: a) neurotyczność, b) ekstrawersję, c) otwartość na doświadczenia, d) ugodowość; e) sumienność. W badaniach nad neurotycznością zauważa się, że takie osoby charakteryzują się myśleniem irracjonalnym. Olbrzymi trud przynosi im kontrola własnych popędów. Sytuacje stresowe wywołują olbrzymie napięcie. Osoby, które mają tą cechę, są skłonne do wrogości, nieuzasadnionego gniewu. Dodatkowo ich poczucie własnej wartości jest bardzo niskie. Osoby, u których występuje niski poziom neurotyczności, są zrównoważone, potrafią się zrelaksować. Doświadczają mniej stresu i napięć, lepiej adaptują się do nowych sytuacji ${ }^{23}$.

Kolejnym czynnikiem jest ekstrawersja, której wysoki poziom determinuje zachowania serdeczne i społeczne. Osoby takie są skłonne, aby poprzez kontakty interpersonalne stymulować siebie. Dodatkowo wśród takich osób

\footnotetext{
20 Zob. G. W. Allport, Becoming: Basic considerations for a psychology and personality, New Haven 1955, s. 88-91.

21 S. C. Kobasa,, Commitment and coping in stress resistance among lawyers, „Journal of Personality and Social Psychology" 42 (1982), s. 707-717.

22 S. C. Kobasa, Stressful life events, personality and health: An inquiry into hardiness, „Journal of Personality and Social Psychology” 37 (1979), s. 1-11.

23 B. Zawadzki, J. Strelau, P. Szczepaniak, M. Śliwińska, Inwentarz osobowości NEO-FFI Costy i McCrae. Adaptacja polska. Podręcznik, Warszawa 1998, s. 70-71.
} 
dominuje pogodny nastrój i optymizm życiowy. Drugim biegunem tego czynnika jest introwersja, która determinuje chęć do odpoczywania w samotności i dystansu wobec relacji społecznych. Osoby introwertyczne to zazwyczaj osoby nieśmiałe ${ }^{24}$.

Związków między neurotycznością a ekstrawersją, w procesie przystosowania jednostki do sytuacji stresowych, doszukiwał się Hans Eysenck ${ }^{25}$. Uważa on, że zrównoważeni ekstrawertycy, tzw. sangwinicy, którzy mają maksymalnie średni poziom neurotyczności oraz ponadprzeciętny poziom ekstrawersji, mają wielkie umiejętności adaptacji. W grupie „lepiej przystosowanych" Eysenck wymienia także flegmatyków, czyli osoby, które mają niski lub przeciętny poziom neurotyczności i ekstrawersję poniżej przeciętnej. Można wnioskować, że wśród najlepiej adaptujących się są zazwyczaj praktycy, działacze społeczni lub tworzący intelektualiści. Do najgorzej przystosowanych należą melancholicy i cholerycy, których charakteryzuje niestabilność emocjonalna.

Osoby z wysoką otwartością na doświadczenia niezależnie od tego, czy muszą przeobrażać swój świat zewnętrzny, czy wewnętrzny, charakteryzują się dużą dozą kreatywności. Wrażliwość estetyczna i chęć rozwoju w kontekście intelektualnym mogą powodować, że osoba kwestionuje autorytety, jednak stara się jednocześnie poznawać nowe wartości o charakterze politycznym i społecznym. Małą otwartość reprezentują osoby, które są konserwatywne nie tylko w swoich poglądach, ale też zachowaniu. Zmiany wywołują u takich osób dyskomfort. Wysoka otwartość na doświadczenia jest elementem konstytutywnym samorozwoju ${ }^{26}$. Badania jakościowe grupy emigrantów polskich w Londynie wskazują otwartość jako pierwszorzędną cechę, stanowiącą predyktor adaptacji do życia na emigracji ${ }^{27}$.

Osoby z dużą ugodowością to osoby, które są skłonne do udzielenia pomocy i życzliwe wobec innych ludzi, pod warunkiem że reprezentują podobne wartości. Można opisać te osoby jako szczere, prostolinijne i empatyczne względem innych. Ugodowość koreluje z mniejszymi trudnościami w relacjach interpersonalnych oraz rzadkimi sytuacjami konfliktów z pra-

\footnotetext{
24 Zob. J. Strelau, Psychologia. Podręcznik akademicki, ${ }^{2}$ Gdańsk 2000, s. 554.

25 H. Eysenck, Opis i pomiar osobowości, „Psychologia Wychowawcza” 3 (1960) nr 19, s. 3-14.

26 A. H. Maslow, Motywacja i osobowość, przeł. P. Sawicka, Warszawa 1990, s. 235.

27 K. Winiecka, Adaptacja społeczna rodzin młodych migrantów polskich mieszkających w Londynie, Wrocław 2015, s. 224-226.
} 
wem. Z kolei osoby o małej ugodowości są nastawione rywalizacyjnie. Badania potwierdzają, że ugodowość jest czynnikiem ułatwiającym przystosowanie do sytuacji kryzysowych ${ }^{28}$.

Ostatnim czynnikiem jest sumienność. Wysoki poziom tej cechy wskazuje na silną wolę i motywację w celu realizacji wyznaczonych przez siebie wcześniej celów. Skrupulatność i punktualność zapewniają tym osobom szeroko rozumiany sukces. Osoby o małej sumienności nie wykonują swoich obowiązków rzetelnie oraz nie mają skonkretyzowanych celów życiowych, przez co dochodzi do rozleniwienia, które ogranicza przystosowanie do nowych warunków. Sumienność jest cechą korelującą z wysokim przystosowaniem do zmieniających się warunków życiowych ${ }^{29}$.

\section{Wartości życiowe a zachowania adaptacyjne}

Równie istotne z punktu widzenia zachowań adaptacyjnych są wartości życiowe jednostki. Maria Misztal wskazuje, że „wartości są to zjawiska ze sfery świadomości, dla których specyficzne jest współwystępowanie komponentów: poznawczego, emocjonalnego i normatywnego. Obok wiedzy o przedmiocie emocjonalnego doń stosunku, elementem konstytuującym wartość jest przekonanie o tym, iż dany przedmiot, stan rzeczy czy sposób działania jest właściwym i akceptowanym społecznie obiektem pragnień i dążeń ludzkich"30.

Według Ewina P. Hollandera ${ }^{31}$ wartości są ściśle związane z głównymi segmentami postaw, wobec czego mogą determinować zachowanie $w$ taki sposób, aby osiągać określone cele. Z kolei Kazimierz Dąbrowski ${ }^{32}$ stwierdza, że hierarchia wartości oparta na „uczuciach wyższych” stanowi szansę rozwoju osoby. Dodatkowo autor wskazuje na związek hierarchii wartości z osobowością. Uważa, że wartości ukierunkowane na związki interperso-

\footnotetext{
28 S. Nikodemska, Struktura JA, obraz siebie i radzenia sobie w sytuacji trudnej, u pacjentów lecznictwa odwykowego, „Świat Problemów” 129 (2003) nr 10, s. 4-7.

29 J. Cieciuch, Kształtowanie się systemu wartości od dzieciństwa do wczesnej dorosłości, Warszawa 2013, s. 238.

30 M. Misztal, Wykształcenie jako wartość, Warszawa 1984, s. 187.

31 E. P. Hollander, Current Perspectives in Social Psychology of Education, New York 1971.

32 K. Dąbrowski, Pasja rozwoju, Warszawa 1988, s. 3-6.
} 
nalne oraz świadome dążenie do rozwoju, są głównymi determinantami rozwoju osobowości z perspektywy indywidualnej i społecznej. Bardziej rozbudowaną teorią, która odnosi się do wartości, jest ta autorstwa Miltona Rokeacha ${ }^{33}$. Według niego wartości są ściśle powiązane z osobowością. System indywidualnych przekonań to innymi słowy osobowość, która składa się z trzech części składowych:

- wartości deskryptywne - są oceniane pod kątem stwierdzenia prawdziwości (prawda, fałsz);

- wartości ewaluatywne - innymi słowy wartościujące (dobry, zły);

- wartości preskryptywne i proskryptywne - orzekają o tym, że przedmiot przekonania jest pożądany lub nie (nakazujące, zakazujące) ${ }^{34}$.

Rokeach na kanwie swojej koncepcji opracował Skalę Wartości, która bada system wartości, charakterystyczny dla młodzieży i dorosłych. W Skali Wartości można dostrzec dwie podstawowe grupy wartości:

- ostateczne - odnoszą się do celu ludzkiej egzystencji, cechą charakterystyczną jest to, że są one ponadsytuacyjne (osobiste i społeczne);

- instrumentalne - są to sposoby realizowania wartości o charakterze ostatecznym (moralne i kompetencyjne).

Rokeach twierdził, że dzięki zbadaniu hierarchii wartości istnieje możliwość zrozumienia osobowości człowieka oraz strategii, które występują $\mathrm{w}$ toku rozwoju psychospołecznego ${ }^{35}$. Brunon Hołyst ${ }^{36}$ zauważa, że w sytuacji, kiedy dobra materialne czy praca mają charakter wyłącznie instrumentalny - czyli są środkiem do realizacji innych celów - to wszelkiego rodzaju kryzysy mają charakter przejściowy i są one nieznaczne. Jednak w sytuacji, w której wartości instrumentalne staną się celem samym w sobie, może dojść do poważnych zaburzeń osobowości. Wysokie znaczenie wartości ostatecznych sprawia, że osoba nie będzie wprawdzie funkcjonować bez kryzysów, ale jej potencjał osobowościowy będzie rozwijany. Sytuacja emigracji jest momentem niezwykle kryzysogennym. Hierarchia wartości i rozmieszczenie poszczególnych wartości ostatecznych i instrumentalnych

\footnotetext{
33 M. Rokeach, The Nature of Human Values, New York-London 1973, s. 18.

34 J. Kościuch, Kwestionariusz Wartości Miltona Rokeacha, „Studia Philosophiae Christianae" 1 (1983) nr 19, s. 224-231.

35 Za: B. Mróz, 20 lat później - osobowość i hierarchia wartości wybitnych aktorów polskich. Badania podlużne, Warszawa 2015, s. 109-110.

36 T. Gałkowski, Rola systemu wartości w procesie psychicznego i społecznego rozwoju jednostki, w: B. Hołyst, System wartości i zdrowie psychiczne, Warszawa 1990, s. 56-61.
} 
może świadczyć o zdrowiu psychicznym jednostki oraz o tym, w jaki sposób adaptuje się do zmian zachodzących w jej życiu. Przewaga znaczenia wartości ostatecznych nad instrumentalnymi daje większą stabilność jednostce i ułatwia jej proces adaptacji.

\section{Metodologia badań}

Badanie ma na celu ustalenie, czy i jakie współzależności występują pomiędzy adaptacją a osobowością oraz adaptacją a wartościami wyznawanymi przez emigranta polskiego. W badaniach kontrolowano płeć, wiek, wykształcenie i posiadanie rodziny na emigracji.

\subsection{Problemy badawcze}

Nawiązując do przeglądu literatury zaprezentowanego w poprzednich częściach niniejszej pracy, wyodrębniono następujące pytania badawcze:

1. Czy cechy osobowości wiążą się z poziomem przystosowania emigranta do życia w Holandii?

2. Czy hierarchia wartości wiąże się z adaptacją do nowej sytuacji życiowej, jaką jest emigracja?

3. Czy posiadanie rodziny wpływa na adaptację do emigracji?

\subsection{Hipotezy badawcze}

Uwzględniając powyższe pytania badawcze, sformułowano następujące hipotezy badawcze:

1. Występują związki między cechami osobowości emigranta a jego przystosowaniem do emigracji.

1.1. Wysoka neurotyczność wiąże się z niską adaptacją do emigracji.

1.2. Wysoka sumienność, ugodowość, otwartość i ekstrawersja wiążą się z wysokim przystosowaniem.

2. Występują związki między hierarchią wartości u emigrantów a ich przystosowaniem.

2.1. Wśród wartości ostatecznych: dojrzała miłość, uznanie społeczne i zabezpieczenie bytu dla rodziny związane są pozytywnie z przystosowaniem. 
2.2. Wysoka pozycja wartości instrumentalnych, takich jak: lojalność, odpowiedzialność i uczynność jest powiązana z wysokim poziomem przystosowania.

3. Osoby wyjeżdżające z rodziną lepiej przystosowują się do życia na emigracji.

\subsection{Charakterystyka grupy badawczej}

$\mathrm{W}$ analizie uwzględniono $\mathrm{n}=200$ przypadków i poddano je analizie. Wśród osób badanych były kobiety $(\mathrm{n}=100)$ i mężczyźni $(\mathrm{n}=100)$, w wieku od 20 do 55 lat, średni wiek osób badanych $M=32,86$, a odchylenie standardowe wynosiło $\mathrm{SD}=8,594$.

\subsection{Procedura badania}

Niniejsze badanie zostało przeprowadzone metodą kwestionariuszową pośród Polaków, którzy mieszkają w Holandii. Respondenci uczestniczący w badaniu otrzymali jednakowy zestaw baterii testu. W jej składzie znajdowała się: metryczka (płeć, wiek, wykształcenie oraz stan cywilny), a także trzy kwestionariusze psychometryczne: a) Ten Item Personality Inventory (TIPI-PL); b) Skala Wartości Rokeacha (RVS); c) Skala Zmian Życiowych (SZŻ). Badanie własne przeprowadzono na terenie Holandii, w okresie od 1 marca do 30 lipca 2018 roku. Osoby badane miały nieograniczony czas na wypełnienie wszystkich testów.

\subsection{Narzędzia badawcze}

\subsubsection{Osobowość - Ten Item Personality Inventory}

Do pomiaru osobowości zastosowano test Ten Item Personality Invento$\mathrm{ry}^{37}$, który spełnia wymagania psychometryczne odnoszące się do trafności i rzetelności. Kwestionariusz składa się z 10 pozycji, z czego na jedną cechę osobowości przypadają dwa przymiotniki. Arkusz jest zgodny z cechami osobowości, w inwentarzu NEO-FFI Costy i McCrae. Badanych było

37 Gosling, S. D., Rentfrow, P. J., Swann, W. B. Jr., A very brief measure of the Big-Five personality domains, „Journal of Research in Personality” 37(2003) 6, s. 504-528. Polska adaptacja testu: A. Sorokowska, A. Słowińska, A. Zbieg, P. Sorokowski, Polska adaptacja testu Ten Item Personality Inventory (TIPI) -TIPI-PL-wersja standardowa i internetowa, Wrocław 2014. 
pięć wymiarów osobowości: neurotyczność, ekstrawersja, sumienność, otwartość na doświadczenia i ugodowość. Zadaniem osoby badanej jest ustosunkowanie się do dziesięciu par twierdzeń, które pozostają na skali 7-stopniowej, od 1 - które oznacza „zdecydowanie się nie zgadzam”, do 7 - „zdecydowanie się zgadzam”. Wynik wszystkich skal stanowi średnią dwóch pozycji. Jedna z pozycji jest odwrócona. Opisywane narzędzie ma satysfakcjonujące wskaźniki zgodności wewnętrznej. Na podstawie przeprowadzonej analizy rzetelności ustalono, że współczynniki alfa Cronbacha dla poszczególnych wartości w polskiej wersji językowej prezentują się następująco: a) otwartość $-a=0,45 ; b)$ ugodowość $-a=0,54$; c) sumienność $-\alpha=0,80 ;$ d) neurotyczność $-\alpha=0,83$; e) ekstrawersja $-\alpha=0,74$.

\subsubsection{Wartości - Skala Wartości Rokeacha}

Narzędzie bada wartości. Skala składa się z dwóch list wartości: 18 wartości ostatecznych i 18 wartości instrumentalnych. Do wartości ostatecznych w arkuszu zaliczają się: 1) wygoda życia, 2) życie ekscytujące, 3) rozumne dokonania, 4) pokój na świecie, 5) piękno świata, 6) równość, 7) trwałość, 8) szczęście, 9) wolność, 10) harmonia wewnętrzna, 11) dojrzała miłość, 12) bezpieczeństwo narodowe, 13) przyjemność, 14) zbawienie, 15) samopoważanie, 16) uznanie społeczne, 17) prawdziwa przyjaźń, 18) mądrość. Wartości instrumentalne to: 1) ambicja, 2) szerokość horyzontów intelektualnych, 3) zdolności, 4) urok, czar osobisty, 5) czystość, 6) odwaga, 7) umiejętność przebaczania, 8) opiekuńczość, 9) uczciwość, 10) twórcza wyobraźnia 11) niezależność, 12) intelektualizm, 13) logiczność, 14) miłość, 15) posłuszeństwo, 16) grzeczność, 17) odpowiedzialność, 18) samokontrola.

Pozycje najwyższe i najniższe w hierarchii stanowią najbardziej stabilnie wartości, pozycje średnie są najbardziej podatne na zmianę. Badanie może być przeprowadzone indywidualnie, ale też grupowo. W celu oszacowania rzetelności narzędzia proponuje się metodę test-retest, która pozwala na ocenę stabilności wyników.

\subsubsection{Adaptacja - Skala Zmian Życiowych}

Skala Zmian Życiowych jest samoopisowym narzędziem służącym do pomiaru wpływu krytycznych lub traumatycznych zdarzeń życiowych na takie obszary funkcjonowania osoby, jak: jej przekonania o wartości i sensie życia, poczucie osobistej siły, głębokość relacji z innymi ludźmi, zmiana systemu wartości oraz wzbogacenie życia duchowego. Wysokie wyniki w tych 
skalach są uznawane za „wzrost potraumatyczny”, który oznacza pozytywną przemianę czy też pozytywne przystosowanie. Z kolei niski wynik interpretowany jest jako brak adaptacji do stresującej sytuacji. Skala Zmian Życiowych ma 19 pytań, ma satysfakcjonującą trafność zbieżną i kryterialną. Zgodność wewnętrzna również na poziomie satysfakcjonującym. Odpowiedzi w kwestionariuszu mają charakter skali pięciopunktowej (od „zdecydowanie zmalał” do „zdecydowanie wzrósł”). Wielkość wartości współczynnika rzetelności (alfa Cronbacha) wynosi 0,80 dla osób pełnoletnich, które są w okresie dwóch lat od krytycznego wydarzenia; 0,90 dla osób, których życiu groziło niebezpieczeństwo. Podział połówkowy Guttmana wskazuje na rzetelność 0,71 . Korelacja międzypołówkowa to 0,51 .

\subsubsection{Pozostałe zmienne}

Poza wymienionymi zmiennymi została zebrana metryczka danych socjodemograficznych, tj. wiek, płeć, wykształcenie, posiadanie rodziny w miejscu emigracji.

\subsection{Prezentacja otrzymanych wyników}

Wyniki zostały poddane analizie w programie STATISTICA 12.5. Początkowo nastąpiło zweryfikowanie normalności rozkładu zmiennych, które zostały poddane analizie. W tym momencie skorzystano $\mathrm{z}$ testu Shapiro-Wilka. Okazało się, że zebrane dane mają rozkład różny od rozkładu normalnego, ponieważ wszystkie analizy wskazały, że poziom istotności to $\mathrm{p}=0,00$; $\mathrm{p}<0,05$. W związku z tym zastosowano do weryfikacji hipotez badawczych nieparametryczne testy statystyczne.

\subsubsection{Osobowość a przystosowanie do emigracji}

Ze względu na rozkład różny od normalnego dla zmiennej przystosowanie do określenia współzależności pomiędzy poszczególnymi cechami osobowości a przystosowaniem wykonano korelację rho-Spearmana. Wyniki przedstawia tabela nr 1. 
Tabela 1. Zależność pomiędzy podstawowymi wymiarami osobowości a przystosowaniem

\begin{tabular}{lcccc}
\hline Para zmiennych & N ważnych & rho-Spearmana & T (n-2) & p \\
\hline Przystosowanie i ekstrawersja & 200 & 0,33 & 3,83 & 0,00 \\
Przystosowanie i ugodowość & 200 & 0,20 & 2,29 & 0,02 \\
Przystosowanie i sumienność & 200 & 0,22 & 2,55 & 0,01 \\
Przystosowanie i neurotyczność & 200 & $-0,19$ & $-2,09$ & 0,04 \\
Przystosowanie i otwartość & 200 & 0,26 & 2,95 & 0,00 \\
\hline
\end{tabular}

Źródło: opracowanie własne.

Rezultaty pokazują, że ekstrawersja istotnie koreluje z poziomem przystosowania. Na podstawie uzyskanego współczynnika korelacji siłę zależności można określić jako przeciętną ( $\mathrm{p}<0,001)$. Dodatni kierunek oznacza, że im większa ekstrawersja, tym wyższy będzie poziom przystosowania do emigracji. Otwartość ma również dodatni związek z przystosowaniem do sytuacji trudnych. Również relacja siły związków pozostaje na przeciętnym poziomie $(\mathrm{p}<0,01)$. Ponadto ugodowość i sumienność także wykazują związek $\mathrm{z}$ adaptacją $\mathrm{o}$ charakterze przeciętnym $(\mathrm{p}<0,05)$. Jedyną zmienną, która wykazuje odwrotny kierunek związku z przystosowaniem, jest neurotyczność $(\mathrm{p}<0,05)$. Oznacza to, że im większa neurotyczność, tym mniejsze przystosowanie do życia na emigracji. Hipoteza pierwsza potwierdza się.

\subsubsection{Związek hierarchii wartości z przystosowaniem}

$\mathrm{W}$ celu rozpatrzenia, czy występują istotne zależności między wartościami instrumentalnymi a ostatecznymi wśród osób będących emigrantami, wykonano nieparametryczną korelację rho-Spearmana.

Tabela 2. Przystosowanie i wartości ostateczne

\begin{tabular}{lcccc}
\hline $\begin{array}{l}\text { Para zmiennych wartości } \\
\text { ostatecznych }\end{array}$ & N ważnych & rho-Spearmana & T (N-2) & p \\
\hline $\begin{array}{l}\text { Przystosowanie i bezpieczeństwo } \\
\text { narodowe }\end{array}$ & 200 & $-0,08$ & $-0,90$ & 0,37 \\
$\begin{array}{l}\text { Przystosowanie i dojrzała miłość } \\
\text { Przystosowanie i mądrość }\end{array}$ & 200 & $-0,23$ & $-2,60$ & 0,01 \\
Przystosowanie i piękno świata & 200 & $-0,44$ & $-5,32$ & 0,00 \\
Przystosowanie i pokój na świecie & 200 & $-0,06$ & $-0,68$ & 0,50 \\
Przystosowanie i prawdziwa & 200 & $-0,37$ & $-4,24$ & 0,00 \\
przyjaźń & & $-0,15$ & $-1,67$ & 0,10
\end{tabular}




\begin{tabular}{|c|c|c|c|c|}
\hline $\begin{array}{l}\text { Przystosowanie i przyjemność } \\
\text { z życia }\end{array}$ & 200 & $-0,09$ & $-0,93$ & 0,35 \\
\hline Przystosowanie i równość ludzi & 200 & $-0,19$ & $-2,13$ & 0,04 \\
\hline Przystosowanie i sukcesy życiowe & 200 & 0,010 & 0,11 & 0,91 \\
\hline $\begin{array}{l}\text { Przystosowanie i szacunek } \\
\text { dla siebie }\end{array}$ & 200 & $-0,29$ & $-3,30$ & 0,00 \\
\hline $\begin{array}{l}\text { Przystosowanie i uznanie } \\
\text { społeczne }\end{array}$ & 200 & $-0,02$ & $-0,32$ & 0,75 \\
\hline $\begin{array}{l}\text { Przystosowanie i wewnętrzny } \\
\text { spokój i harmonia }\end{array}$ & 200 & $-0,23$ & $-2,56$ & 0,01 \\
\hline $\begin{array}{l}\text { Przystosowanie i wolność } \\
\text { osobista }\end{array}$ & 200 & $-0,28$ & $-3,12$ & 0,00 \\
\hline $\begin{array}{l}\text { Przystosowanie i zabezpieczenie } \\
\text { bytu dla rodziny }\end{array}$ & 200 & $-0,31$ & $-3,48$ & 0,00 \\
\hline Przystosowanie i zbawienie & 200 & $-0,20$ & $-2,17$ & 0,03 \\
\hline Przystosowanie i zdrowie & 200 & $-0,29$ & $-3,33$ & 0,00 \\
\hline $\begin{array}{l}\text { Przystosowanie i życie pełne } \\
\text { wrażeń }\end{array}$ & 200 & $-0,19$ & $-2,14$ & 0,03 \\
\hline
\end{tabular}

Źródło: opracowanie własne.

Z analizy wynika, że występują ujemne zależności pomiędzy przystosowaniem do życia na emigracji a takimi wartościami ostatecznymi, jak: dojrzała miłość, mądrość, pokój na świecie, równość ludzi, szacunek dla siebie, wewnętrzny spokój, wolność osobista, zabezpieczenie bytu dla rodziny, zbawienie, zdrowie oraz życie pełne wrażeń. Wśród nich znajdują się wyłącznie wartości istotnie skorelowane. Uzyskane współczynniki korelacji mieszczą się w zakresie -0,19 do -0,34. Siła istotnych zależności waha się od słabej do przeciętnej. Wśród wartości ostatecznych charakteryzujących wysokie przystosowanie, na podstawie hipotez, należą dojrzała miłość i zabezpieczenie bytu dla rodziny. Wartością nieistotną jest uznanie społeczne.

Tabela 3. Przystosowanie i wartości instrumentalne

\begin{tabular}{lcccc}
\hline $\begin{array}{l}\text { Para zmiennych wartości } \\
\text { instrumentalnych }\end{array}$ & N ważnych & rho-Spearmana & T (N-2) & $p$ \\
\hline Przystosowanie i ambicja & 200 & $-0,05$ & $-0,48$ & 0,63 \\
Przystosowanie i czystość & 200 & $-0,09$ & $-0,96$ & 0,34 \\
$\begin{array}{l}\text { Przystosowanie i gotowość } \\
\text { kochania }\end{array}$ & 200 & $-0,14$ & $-1,55$ & 0,12 \\
Przystosowanie i grzeczność & 200 & $-0,18$ & $-1,96$ & 0,05
\end{tabular}




$\begin{array}{llccc}\text { Przystosowanie i logiczność } & 200 & -0,21 & -2,42 & 0,02 \\ \text { myślenia } & 200 & -0,16 & -1,70 & 0,10 \\ \text { Przystosowanie i lojalność } & 200 & -0,21 & -2,30 & 0,02 \\ \text { Przystosowanie i odpowiedzialność } & 200 & -0,09 & -0,97 & 0,34 \\ \text { Przystosowanie i odwaga } & 200 & -0,20 & -2,18 & 0,03 \\ \text { Przystosowanie i opanowanie } & 200 & -0,22 & -2,40 & 0,18 \\ \text { Przystosowanie i pomysłowość } & 200 & -0,10 & -1,03 & 0,31 \\ \text { Przystosowanie i posłuszeństwo } & 200 & -0,19 & -2,12 & 0,04 \\ \text { Przystosowanie i refleksyjność } & 200 & 0,00 & 0,05 & 0,96 \\ \text { Przystosowanie i samodzielność } & 200 & -0,25 & -2,67 & 0,00 \\ \text { Przystosowanie i tolerancja } & 200 & -0,07 & -0,73 & 0,47 \\ \text { Przystosowanie i uczciwość } & 200 & -0,23 & -2,52 & 0,01 \\ \text { Przystosowanie i uczynność } & -0,38 & -4,39 & 0,00 \\ \text { Przystosowanie i wyrozumiałość } & 200 & 0,00 & 0,10 & 0,92 \\ \text { Przystosowanie i zdolność } & 200 & & & \end{array}$

Źródło: opracowanie własne.

Wyniki wskazują na występowanie ujemnych zależności między przystosowaniem badanych do emigracji a takimi wartościami instrumentalnymi, jak: logiczność myślenia, odpowiedzialność, opanowanie, pomysłowość, refleksyjność, tolerancja, uczynność oraz wyrozumiałość. Współczynniki korelacji wahają się od -0,19 do -0,38. Siła tych zależności znajduje się między słabą a przeciętną. Wśród wartości instrumentalnych, które według hipotezy stanowią predyktor wysokiego poziomu przystosowania, są odpowiedzialność i uczynność. Lojalność jest wartością niekorelującą istotnie ze zmienną przystosowanie. Analizując znaczenie wartości ostatecznych i instrumentalnych, wykazano, że większość zmiennych o charakterze społecznym, czyli: dojrzała miłość, zabezpieczenie bytu dla rodziny, odpowiedzialność i uczynność, istotnie koreluje ze zmienną przystosowanie. W pozostałych przypadkach nie odnotowano korelacji istotnych. Zatem hipoteza zostaje obalona.

\subsubsection{Związek posiadania rodziny z przystosowaniem na emigracji} Początkowo, w celu sprawdzenia normalności rozkładu, wykonano test Shapiro-Wilka dla zmiennej zależnej przystosowanie. Okazało się, że $\mathrm{p}=0,00$; $\mathrm{p}<0,05$. Rozkład okazał się zatem różny od normalnego. Na tej podstawie został wykonany test nieparametryczny U Manna-Whitneya. Wyniki zaprezentowano w tabeli 4. 
Tabela 4. Przystosowanie a posiadanie rodziny na emigracji

Zmienna grupująca: Emigrowanie z rodziną

\begin{tabular}{llllll}
\hline & & & & Nie & Tak \\
Zmienne: & $\mathrm{U}$ & $\mathrm{Z}$ & $\mathrm{p}$ & $\mathrm{N}=106$ & $\mathrm{~N}=94$ \\
& & & & $\mathrm{M}(\mathrm{SD})$ & $\mathrm{M}(\mathrm{SD})$ \\
Adaptacja & 2679,00 & $-5,64$ & $0,00^{* * *}$ & $60,03(5,00)$ & $72,60(6,32)$ \\
\hline
\end{tabular}

${ }^{*} p<0,05^{* *} p<0,01{ }^{* *} p<0,001$

Źródło: opracowanie własne.

Okazało się, że występują różnice istotne statystycznie między osobami emigrującymi i nieemigrującymi $z$ rodziną w poziomie przystosowania, ponieważ poziom istotności $p=0,00 ; p<0,001$. Uwzględniając statystyki opisowe, można stwierdzić, iż osoby emigrujące z rodziną $(M=72,60)$ lepiej adaptują się do emigracji w porównaniu z osobami przebywających na emigracji bez rodziny $(M=60,03)$. Na podstawie przedstawionych wyników, możemy wskazać, że hipoteza dotycząca różnic pomiędzy osobami emigrującymi i nieemigrującymi z rodziną pod względem poziomu przystosowania potwierdza się.

\section{Dyskusja}

Uzyskane wyniki badań potwierdziły znaczną część hipotez. Istnieją zależności między składowymi osobowości osób emigrujących a ich przystosowaniem do warunków na emigracji. Sumienność, ugodowość, ekstrawersja i otwartość na doświadczenia okazały się w sposób umiarkowany istotne statystycznie w związku z przystosowaniem. Oznacza to, że wysoki współczynnik tych cech wiąże się z lepszą adaptacją do zmian życiowych, jakie wynikają z faktu emigracji. Jedyną cechą osobowości, która może ją utrudniać, jest neurotyzm. Wysokie wyniki w tej podskali oznaczają mniejsze prawdopodobieństwo adaptacji psychicznej. Wyniki badań, które potwierdzają wnioski do hipotezy pierwszej, można odnaleźć również w literatu- 
rze. Według teorii cech Wielkiej Piątki McCrae’a i Costy ${ }^{38}$ wyniki związane z neurotyzmem charakteryzują osoby, które doświadczają bardzo często negatywnych stanów emocjonalnych. Może to powodować mniejszą wiarę we własne możliwości i prowadzić do powstania trudności w adaptacji do nowych, stresujących wydarzeń.

Potwierdzenia, że ekstrawersja jest czynnikiem, który pomaga osobie przystosować się do nowych sytuacji, można szukać w badaniach. Otóż okazuje się, że ekstrawertycy charakteryzują się dużą potrzebą interakcji społecznych. Osoby takie są aktywne i energiczne, mają zdolności do częstego przeżywania radości. Badania Skehana potwierdzają ${ }^{39}$, że ekstrawertycy są skłonni częściej korzystać z języka obcego, którego nauczyli się podczas zajęć. Taka aktywność może być szczególnie cenna na emigracji, ponieważ następuje wtedy wzrost interakcji z nowym społeczeństwem. Wykazano również, że otwartość na doświadczenia może być predyktorem wyższego przystosowania do życia na emigracji. Otwartość na doświadczenia to innymi słowy tendencja do przejawiania ciekawości o charakterze poznawczym oraz spora tolerancja na wszelkiego rodzaju nowości. Badacze zaznaczają, że niski poziom tej cechy charakteryzuje osoby konserwatywne, które nie zmieniają swoich poglądów. Jest to niewątpliwie cecha ułatwiająca przystosowanie, $\mathrm{z}$ drugiej zaś strony prowokuje do poszukiwania nowych doświadczeń. Takim doświadczeniem jest emigracja. W celu zbadania tego związku w kolejnych badaniach należałoby wziąć pod uwagę również motywację wyjazdu ${ }^{40}$. W odniesieniu do ugodowości, która również wykazała umiarkowane właściwości statystyczne z przystosowaniem, należy zaznaczyć, że zdaniem badaczy cecha ta związana jest ściśle z ufnością wobec innych ludzi. Dodatkowo takie osoby charakteryzują się nastawieniem na współpracę i altruistyczną motywacją zachowań. Jednakże wskazuje się również, że osoby o wysokiej ugodowości chętnie idą na ustępstwa $\mathrm{z}$ tymi osobami o podobnej hierarchii wartości. Holandia jest na pewno krajem innym niż Polska pod względem wyznawanych wartości. Zbadanie hierarchii wartości wśród Polaków wyjeżdżających do innych

\footnotetext{
38 B. Zawadzki, J. Strelau, P. Szczepaniak, M. Śliwińska, Inwentarz osobowości NEO-FFI Costy i McCrae. Adaptacja polska. Podręcznik, dz. cyt., s. 70-71.

39 P. Skehan, Individual Differences in Second Language Learning, London 1989, s. $171-174$.

40 K. Kmiecik-Baran, Poczucie osamotnienia - charakterystyka zjawiska, „Przegląd Psychologiczny” 4 (1988), s. 1081-1095.
} 
państw oraz hierarchii wartości, która jest najbardziej charakterystyczna dla państw będących celem emigracji, mogłoby wykazać związki motywacyjne wyboru właśnie tego, a nie innego państwa ${ }^{41}$. Ostatnią zmienną badaną w obrębie osobowości była sumienność. Zgodnie z hipotezą okazało się, że osoby charakteryzujące się wysoką sumiennością są lepiej przystosowane do emigracji niż osoby z niską sumiennością. Związek między zmiennymi był umiarkowany. Ludzie sumienni to inaczej mówiąc osoby o wysokim poziomie obowiązkowości. Rzetelnie wykonują swoją pracę oraz są bardzo wytrwałe w swoich działaniach, jeżeli ich cel jest skonkretyzowany. Cecha może w umiarkowany sposób ułatwiać adaptację do emigracji, ponieważ najczęstszą grupą emigrantów są ci, którzy podejmują pracę za granicą.

W kontekście drugiej hipotezy, jaką było ukierunkowanie wartości ostatecznych i instrumentalnych na te, o charakterze społecznym tj.: dojrzała miłość, uznanie społeczne i zabezpieczenie bytu dla rodziny, lojalność, odpowiedzialność i uczynność, to została ona obalona. Uznanie społeczne i lojalność są wartościami niepotwierdzonymi. Pozostałe wartości, jak dojrzała miłość, zabezpieczenie bytu dla rodziny, uczynność i odpowiedzialność, pojawiają się w wielu badaniach ${ }^{42}$. Niniejsze wartości stanowią wyraz przystosowania społecznego. Badanie wartości jest niezwykle ważnym obszarem badań - zdaniem Dąbrowskiego realizowanie wartości ludzkich, uczuć wyższych stanowi ważny komponent zdrowia psychicznego, które jest związane ściśle z rozwojem indywidualnym, ale też rozwojem człowieka w społeczeństwie.

Hipoteza trzecia, mówiąca o wysokim przystosowaniu do emigracji osób, które wyjechały wspólnie z rodziną, została potwierdzona. Jest to zgodne z badaniami nad emigracją o charakterze wahadłowym, która prowadzi do rozpadu więzi społecznych, a to $z$ kolei do przeżywania głębiej traumy zmiany społecznej ${ }^{43}$.

41 J. Cieciuch, Kształtowanie się systemu wartości od dzieciństwa do wczesnej dorosłości, dz. cyt., s. 68.

42 M. Czerniawska, Empatia a system wartości, „Przegląd Psychologiczny” 45 (2002) nr 1, s. 7-18.

43 A. Pawlak, Psychospołeczne uwarunkowania zdrowia emigrantów i ich rodzin $w$ świetle własnych badań jakościowych, „Przegląd Socjologiczny” 61 (2012) nr 2, s. 177-203. 


\section{Bibliografia}

Allport G. W., Becoming: Basic considerations for a psychology and personality, New Haven 1955.

Aronson E., Wilson T. D., Akert R. M., Psychologia społeczna, przekł. A. Bezwińska i in., Poznań 1997.

Bernacka R. E., Osobowościowy mechanizm konformizmu i nonkonformizmu - specyfika funkcjonowania i przejawy w zachowaniu, „Psychologia Rozwojowa" 2 (2005) nr 2, s.73-82.

Cieciuch J., Kształtowanie się systemu wartości od dzieciństwa do wczesnej dorosłości, Warszawa 2013.

Colson M., Coping with absent parents, Hastings 2011.

Costa P. T., McCrae R. R., Revised NEO Personality Inventory (NEO-PI-R) and NEO Five-Factor Inventory (NEO-FFI) professional manual, Odessa 1992.

Czerniawska M., Empatia a system wartości, „Przegląd Psychologiczny” 45 (2002) nr 1, s. 7-18.

Dąbrowski K., Pasja rozwoju, Warszawa 1988.

Dąbrowski K., Trud istnienia, Warszawa 1975.

Dąbrowski K., Wprowadzenie do higieny psychicznej, Warszawa 1979.

Dąbrowski P., Napierała J., Piekut A., Migracje międzynarodowe: Polska Unia Europejska - Europa Wschodnia, „Biuletyn Migracyjny” 14 (2007), s. $1-10$.

Eysenck H., Opis i pomiar osobowości, „Psychologia Wychowawcza” 3 (1960) nr 19, s. 3-14.

Gałkowski T., Rola systemu wartości w procesie psychicznego i społecznego rozwoju jednostki, w: B. Hołyst, System wartości i zdrowie psychiczne, Warszawa 1990, s. 56-61.

Górny A., Kaczmarczyk P., Uwarunkowania i mechanizmy migracji zarobkowych w świetle wybranych koncepcji teoretycznych, „Instytut Studiów Społecznych UE” 49 (2003), s. 10-21.

Hollander E. P., Current Perspectives in Social Psychology of Education, New York 1971.

Kmiecik-Baran K., Poczucie osamotnienia - charakterystyka zjawiska, „Przegląd Psychologiczny" 4 (1988), s. 1081-1095. 
Kobasa S. C., Commitment and coping in stress resistance among lawyers, „Journal of Personality and Social Psychology” 42 (1982), s. 707-717.

Kobasa S. C., Stressful life events, personality and health: An inquiry into hardiness, „Journal of Personality and Social Psychology” 37 (1979), s. 1-11.

Kościuch J., Kwestionariusz Wartości Miltona Rokeacha, „Studia Philosophiae Christianae" 1 (1983) nr 19, s. 224-231.

Kubitsky J., Psychologia migracji, Warszawa 2012.

Kumaniecki K., Słownik łacińsko-polski, Warszawa 1964.

Maslow A. H., Motywacja i osobowość, przeł. P. Sawicka, Warszawa 1990.

Misztal M., Wykształcenie jako wartość, Warszawa 1984.

Mróz B., 20 lat później - osobowość i hierarchia wartości wybitnych aktorów polskich. Badania podłużne, Warszawa 2015.

Nikodemska S., Struktura JA, obraz siebie i radzenia sobie $w$ sytuacji trudnej, u pacjentów lecznictwa odwykowego, „Świat Problemów” 129 (2003) nr 10, s. 4-7.

Pawlak A., Psychospołeczne uwarunkowania zdrowia emigrantów i ich rodzin $w$ świetle własnych badań jakościowych, „Przegląd Socjologiczny” 61 (2012) nr 2, s. 177-203.

Petersen W., A General Typology of Migration, „American Sociological Review" 53 (1958), s. 256-266.

Popek S., Kwestionariusz Twórczego Zachowania KANH, Lublin 2000.

Rokeach M., The Nature of Human Values, New York-London 1973.

Skehan P., Individual Differences in Second Language Learning, London 1989.

Skorny Z., Mechanizmy regulacyjne ludzkiego działania, Warszawa 1989.

Śliwak J., Reizer U., Partyka J., Poczucie osamotnienia a przystosowanie społeczne, „Studia Socialia Cracoviensia” 7 (2015) nr 1, s. 61-78.

Sorokowska, A., Słowińska A., Zbieg A., Sorokowski P., Polska adaptacja testu Ten Item Personality Inventory (TIPI) -TIPI-PL-wersja standardowa $i$ internetowa, Wrocław 2014.

Strelau J., Psychologia. Podręcznik akademicki, ${ }^{2}$ Gdańsk 2000.

Świętoniowska J., Starzenie się społeczeństwa europejskiego w kontekście kryzysu światowego. Czy UE nadal ma szansę stać się najbardziej konkurencyjna gospodarka światową?, „Zeszyty Naukowe Zakładu Europeistyki” 3 (2009) nr 11, s. 86-105. 
Tomaszewski T., O możliwościach jednostki w sytuacjach przemian społecznych, „Kolokwia Psychologiczne” 2 (1993) nr 11, s. 20-28.

Winiecka K., Adaptacja społeczna rodzin młodych migrantów polskich mieszkających w Londynie, Wrocław 2015.

Zawadzki B., Strelau J., Szczepaniak P., Śliwińska M., Inwentarz osobowości NEO-FFI Costy i McCrae. Adaptacja polska. Podręcznik, Warszawa 1998. 